\title{
Eutrophication: Impact of Excess Nutrient Status in Lake Water Ecosystem
}

\author{
Hemant Pathak ${ }^{1 *}$ and Deepak Pathak ${ }^{2}$
}

${ }^{1}$ Department of Chemistry, Indra Gandhi Govt. Engineering College, Sagar, MP, India

${ }^{2}$ Department of Chemistry, Govt. S. L. P. College, Morar, Gwalior, MP, India

\begin{abstract}
Sagar Lake located in Sagar city, Madhya Pradesh, India has been subjected to domestic and agricultural wastewater discharges from many decades. An attempt has been made to find the seasonal quality of water in Sagar lake, in order to adopt a statistical model to examine water quality. As a result of eutrophication, quality of lake water has been continuously degraded, this result in increased content of nitrates in soil frequently which leads to undesirable changes in vegetation composition and many plant species. The physicochemical characteristics of water samples from six sampling points during three seasons were analyzed in order to determine the contaminants in lake water. Results were analyzed by using correlation analysis, multi-regression analysis and statistical modeling. The obtained results were compared with water quality standards and standard values recommended by World Health Organization (WHO), and it was found that most of the water samples were highly polluted by sewage. To minimize the complexity and dimensionality of large set of data a Systematic calculation of correlation coefficient between water quality parameters has been applied. The significant correlation has been further verified by using significance level. The results of this study clearly demonstrate the usefulness of multivariate statistical analysis in hydro chemical investigation.
\end{abstract}

Keywords: Eutrophication; Correlation analysis; Multi-regression analysis

\section{Introduction}

Eutrophication can be defined as by which increasing nutrients cause a change of the nutritional status of a given body of water. (Provide reference). This enhanced plant growth (algal bloom), reduces dissolved oxygen in the water when dead plant material decomposes and can cause other organisms to die. Enrichment of aquatic systems by addition of fertilizers into lakes is subject to adverse impacts. Phosphorus is often regarded as the main culprit in cases of eutrophication in lakes subjected to point source pollution from sewage (Provide reference). Agriculture runoff, pollution from septic systems and sewers, and other human-related activities increase the flux of both inorganic nutrients and organic substances water. Elevated atmospheric compounds of nitrogen can increase soil nitrogen availability.

Sagar Lake is situated in the heart of Sagar city $\left(23^{\circ} 50^{\prime} \mathrm{N}\right.$ latitude and $78^{\circ} 45^{\prime} \mathrm{E}$ longitude and $517 \mathrm{MSL}$ ), Madhya Pradesh (State), India with an area of $1.37 \mathrm{sq}$. km. It is a shallow lake with a small catchment (11.06 sq. km). Due to the rapid industrial and agricultural development around the city and transport of sewage water into the lake, it was observed increased contaminants were observed in the lake. From past few years we have been conducting several research studies on Sagar Lake pollution [1-11].

A vital key to the management of Lake Eutrophication has been the development of models linking water body nutrient concentrations to aspects of water quality that are considered by the public to be important and worth preserving [12]. The development of quantitative models that relate external nutrient inputs to the resulting water column concentrations of nutrients in the water body itself was a second key development in eutrophication research [13].

In continuing our research on Sagar Lake pollution, we carried to explore the increased eutrophication in Sagar Lake. In this study we have applied multivariate methods to determine interdependency of quality parameters.

\section{Materials and Methods}

Water samples from 6 sampling places viz. S1- Lake centre, S2-
Chakra Ghat, S3 -Gau Ghat, S4-Ganesh Ghat, S5-Dhobi Ghat, S6Sanjay drive, were collected in Polyethylene bottles. The samples were pre-washed with nitric acid and after sample collection analyses were performed as soon as the samples were carried to the laboratory. All the samples were stored in an ice chest at a temperature of $<4^{\circ} \mathrm{C}$. Ground water sampling was performed three times at Pre to Post monsoon. Samples were collected regularly throughout the seasons. The samples were analyzed for 26 quality parameters using standard analytical techniques by American Public health association [14]. All the chemicals used were of analytical reagent grade. Regression analysis, multiple regression analysis for the total data points were carried out using SPSS.11 and WINKS SDA software. The nature of correlations between parameters was determined based on the correlation coefficient obtained. Data obtained from chemical analysis was compared with WHO [15] guidelines.

\section{Results and Discussion}

In aquatic environments, enhanced growth of choking aquatic vegetation or phytoplankton i.e. algal bloom) disrupts normal functioning of the ecosystem, causing a variety of problems. Human society is impacted as well: eutrophication decreases the resource value of rivers, lakes, and estuaries such that recreation, fishing, hunting, and aesthetic enjoyment are hindered (Figure 1).

Results of correlation analysis show that all applied water quality parameters are strongly related with each other. Interrelationships were established between some physicochemical water pollution indicators where reliable correlations were established using regression analysis (Table 1).

*Corresponding author: Hemant Pathak, Department of Chemistry, Indra Gandh Govt. Engineering College, Sagar, MP, India, E-mail: hemantp1981@yahoo.co.in

Received May 19, 2012; Accepted June 20, 2012; Published June 22, 2012

Citation: Pathak H, Pathak D (2012) Eutrophication: Impact of Excess Nutrient Status in Lake Water Ecosystem. J Environ Anal Toxicol 2:148. doi:10.4172/2161 0525.1000148

Copyright: ( 2012 Pathak $\mathrm{H}$, et al. This is an open-access article distributed under the terms of the Creative Commons Attribution License, which permits unrestricted use, distribution, and reproduction in any medium, provided the original author and source are credited. 
Citation: Pathak H, Pathak D (2012) Eutrophication: Impact of Excess Nutrient Status in Lake Water Ecosystem. J Environ Anal Toxicol 2:148. doi:10.4172/2161-0525.1000148

Multiple regression analysis method was used to evaluate relationship between DO and among other water properties. Identification of variables (Turbidity, BOD, Conductivity, $\mathrm{pH}$, Residual chlorine, o-phosphate, Nitrate, Ammonia, Fluoride, Iron) which have significant and separate effects on the dependent variables.

Regression models were constructed to predict the constituents. BOD tests only measures biodegradable fraction of the total potential DO consumption of a water sample, while COD tests measures the oxygen demand created by toxic organic and inorganic compounds as well as by biodegradable substances (Table 2 data included as supplementary).

Below given figure 2 (data included as supplementary) represent Regression curve between the mean chemical Parameters (independent) and the mean DO (dependent) in Lakes water Samples. This indicates the reliability of the relationships which suggests that it can be used to predict the levels of pollution by the parameters investigated and possibly offering a preventive measure prior to detailed investigation of the Lake water or in pollution monitoring (Table 3 data included as supplementary).

Results have shown that the Sagar Lake contains high concentrations of nitrates and phosphates, which led to the quick growth as well as death of plants and algae. The toxicity of Lake sites is therefore usually not of an acute, but of a chronic nature, as humans as well as aquatic life are typically exposed only to the low concentrations in water, which however can be maintained over a long period of time in the surroundings of a contaminated site also dependent on rainfall events. Eutrophication is frequently a result of nutrient pollution such as the release of sewage effluent into natural waters, a low concentration of dissolved oxygen. Following adverse ecological effects of eutrophication on Sagar lake waters Increased biomass of phytoplankton.

- Toxic or inedible phytoplankton species

- Decreases in water transparency

- Taste, odor problems

- Dissolved oxygen depletion

- Increased incidences of fish kills

- Loss of desirable fish species

- Decreases in perceived aesthetic value of the water body
At certain $\mathrm{pH}$ levels, higher $\mathrm{NH}_{3}$ are toxic to aquatic life, therefore detrimental to the ecological balance of water bodies. Higher concentrations could be an indication of organic pollution such as from domestic sewage, industrial waste and fertilizer run-off. Natural seasonal fluctuations also occur as a result of the death and decay of aquatic organisms, particularly phytoplankton and bacteria in nutritionally rich waters (Table 4 ).

A sudden increase in orthophosphate in Lake water stimulated great increases in the growth of algae, as well as other aquatic plants. Algal blooms can lead to depletion of the oxygen that is dissolved in the water. Phosphates level increased through the breakdown of organic debris and sewage. Low DO values indicating heavy contamination by organic matter due to increased value of BOD and COD indicated the high pollution load produce by waste matter. Higher level of eutrophication in Sagar Lake leads to decrease in DO value. Algal blooms potentially produce toxins and can lead to depletion of the oxygen that is dissolved in the water (Table 5).

Greenish yellow Coloured water restricts the penetration of light, which subsequently retard the photosynthetic reactions. This also indirectly affects the reoxygenation capacity of receiving water. Warm waters are more susceptible to eutrophication a build-up of nutrients and possible algal blooms because photosynthesis and bacterial decomposition both work faster at higher temperatures. Algal blooms limit the sunlight available to bottom-dwelling organisms and cause wide swings in the amount of dissolved oxygen in the water. Nutrients can come from many sources, such as fertilizers applied to agricultural fields, domestic drainage, municipal sewage, deposition of nitrogen from the atmosphere and erosion of soil containing nutrients from nearby catchment area.

The $\mathrm{pH}$ values of Sagar Lake water samples are alkaline in nature. Higher $\mathrm{pH}$ value indicated higher degree of eutrophication in Lake.

The high value of chloride content an indication of organic pollution due to the disposal of industrial, sewage effluents, agricultural and road run-off. Higher Ammonia indicated organic pollution. This arising from the breakdown of nitrogenous organic and inorganic matter in Lakes water, excretion by biota, reduction of the nitrogen gas in water

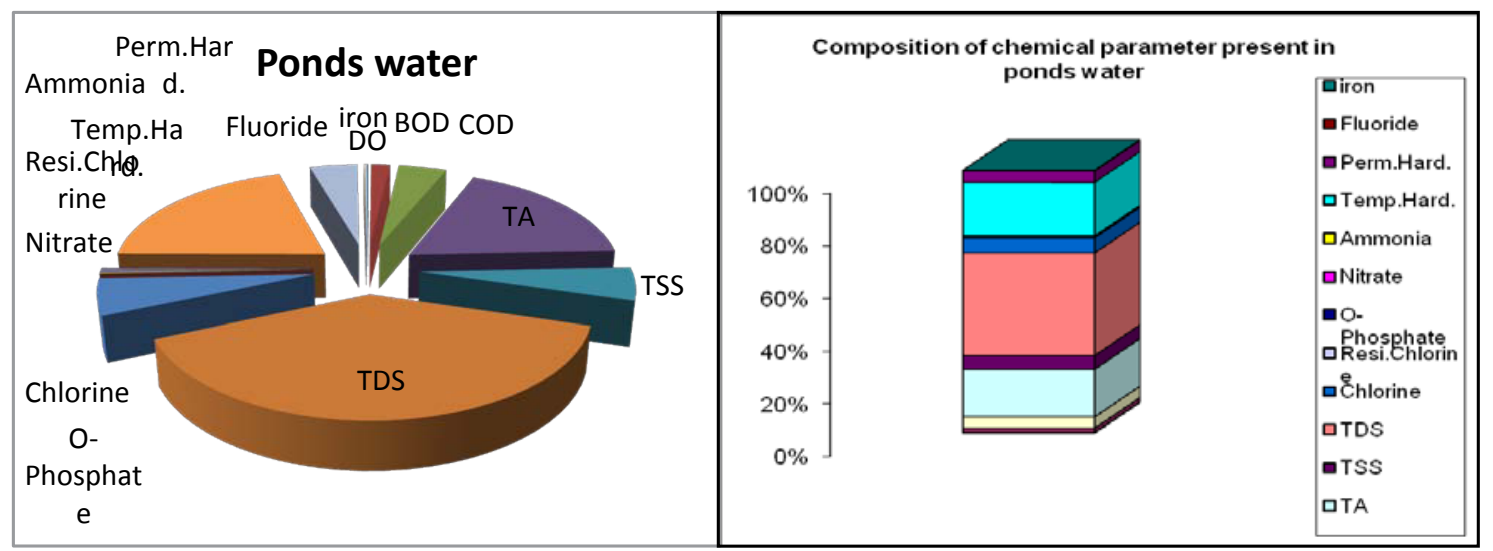

Figure 1: The statistical analysis of the experimentally estimated water quality parameters on water samples yielded the range of the variation, mean, standard deviation and co-efficient of variation. 
Citation: Pathak H, Pathak D (2012) Eutrophication: Impact of Excess Nutrient Status in Lake Water Ecosystem. J Environ Anal Toxicol 2:148. doi:10.4172/2161-0525.1000148

Page 3 of 5

\begin{tabular}{|c|c|c|c|c|c|c|c|c|c|c|c|c|}
\hline \multicolumn{13}{|c|}{ Descriptive Statistics } \\
\hline & \multirow{2}{*}{\begin{tabular}{|l|} 
Range \\
Statistic \\
\end{tabular}} & \multirow{2}{*}{$\begin{array}{l}\text { Minimum } \\
\text { Statistic }\end{array}$} & \multirow{2}{*}{$\begin{array}{l}\text { Maximum } \\
\text { Statistic }\end{array}$} & \multirow{2}{*}{$\begin{array}{l}\text { Sum } \\
\text { Statistic }\end{array}$} & \multicolumn{2}{|l|}{ Mean } & \multirow{2}{*}{$\begin{array}{l}\text { Std. } \\
\text { Statistic }\end{array}$} & \multirow{2}{*}{$\begin{array}{l}\text { Variance } \\
\text { Statistic }\end{array}$} & \multicolumn{2}{|c|}{ Skewness } & \multicolumn{2}{|l|}{ Kurtosis } \\
\hline & & & & & Statistic & Std. Error & & & Statistic & Std. Error & Statistic & Std. Error \\
\hline $\begin{array}{l}\text { TEMPRATURE } \\
\text { COLOUR } \\
\text { pH } \\
\text { TURBIDITY } \\
\text { DO } \\
\text { BOD } \\
\text { COD } \\
\text { CONDUCTIVITY } \\
\text { ALKALINITY } \\
\text { TS } \\
\text { TSS } \\
\text { TDS } \\
\text { CHLORIDE } \\
\text { RESICHLORINE } \\
\text { PHOSPHATE } \\
\text { NITRATE } \\
\text { AMMONIA } \\
\text { TH } \\
\text { TEMP. HARD. } \\
\text { PERM. HARD. } \\
\text { Ca HARDNESS } \\
\text { Mg HARDNESS } \\
\text { FLUORIDE } \\
\text { IRON } \\
\text { Ca CONTENT } \\
\text { Mg CONTENT }\end{array}$ & $\begin{array}{l}.00 \\
15.00 \\
.43 \\
13.00 \\
.80 \\
14.80 \\
19.02 \\
.449 \\
50.00 \\
290.14 \\
68.89 \\
244.34 \\
59.90 \\
.12 \\
.68 \\
2.46 \\
.06 \\
109.69 \\
145.30 \\
113.91 \\
102.11 \\
8.710 \\
.17 \\
1.83 \\
40.93 \\
2.11\end{array}$ & $\begin{array}{l}25.30 \\
39.00 \\
9.24 \\
25.00 \\
2.21 \\
32.80 \\
85.29 \\
1.220 \\
346.00 \\
944.09 \\
98.26 \\
845.83 \\
126.00 \\
.14 \\
4.89 \\
8.28 \\
.43 \\
464.65 \\
347.16 \\
78.30 \\
332.35 \\
131.900 \\
1.20 \\
2.27 \\
133.20 \\
32.05\end{array}$ & $\begin{array}{l}25.30 \\
54.00 \\
9.67 \\
38.00 \\
3.01 \\
47.60 \\
104.31 \\
1.669 \\
396.00 \\
1234.23 \\
167.15 \\
1090.17 \\
185.90 \\
.26 \\
5.57 \\
10.74 \\
.49 \\
574.34 \\
492.46 \\
192.21 \\
434.46 \\
140.610 \\
1.37 \\
4.10 \\
174.13 \\
34.16\end{array}$ & $\begin{array}{l}151.80 \\
274.00 \\
56.63 \\
200.00 \\
15.24 \\
245.40 \\
559.13 \\
8.739 \\
2188.00 \\
6877.02 \\
805.35 \\
5971.67 \\
833.60 \\
1.16 \\
30.71 \\
55.71 \\
2.77 \\
3125.98 \\
2355.27 \\
760.71 \\
2306.69 \\
819.290 \\
7.74 \\
18.45 \\
924.49 \\
199.06\end{array}$ & $\begin{array}{l}25.3000 \\
45.6667 \\
9.4383 \\
33.3333 \\
2.5400 \\
40.9000 \\
93.1883 \\
1.45650 \\
364.6667 \\
1146.1700 \\
134.2250 \\
995.2783 \\
138.9333 \\
.1933 \\
5.1183 \\
9.2850 \\
.4617 \\
520.9967 \\
392.5450 \\
126.7850 \\
384.4483 \\
136.54833 \\
1.2900 \\
3.0750 \\
154.0817 \\
33.1773\end{array}$ & $\begin{array}{l}.0000 \\
2.2755 \\
.0789 \\
2.0602 \\
.1238 \\
2.2377 \\
2.8621 \\
.06480 \\
8.4050 \\
43.8683 \\
10.0183 \\
35.0998 \\
9.5200 \\
.0206 \\
.1125 \\
.3473 \\
.0128 \\
22.5433 \\
22.2484 \\
16.7316 \\
21.1556 \\
1.53674 \\
.0263 \\
.2705 \\
8.4792 \\
.3735\end{array}$ & $\begin{array}{l}.00000 \\
5.57375 \\
.19333 \\
5.04645 \\
.30318 \\
5.48124 \\
7.01066 \\
.158717 \\
20.58802 \\
107.45484 \\
24.53973 \\
85.97657 \\
23.31906 \\
.05046 \\
.27564 \\
.85081 \\
.03125 \\
55.21962 \\
54.49713 \\
40.98384 \\
51.82054 \\
3.764218 \\
.06450 \\
.66259 \\
20.76964 \\
.91486\end{array}$ & $\begin{array}{l}.000 \\
31.067 \\
.037 \\
25.467 \\
.092 \\
30.044 \\
49.149 \\
.025 \\
423.867 \\
11546.542 \\
602.198 \\
7391.970 \\
543.779 \\
.003 \\
.076 \\
.724 \\
.001 \\
3049.207 \\
2969.937 \\
1679.675 \\
2685.368 \\
14.169 \\
.004 \\
.439 \\
431.378 \\
.837\end{array}$ & $\begin{array}{l}.453 \\
.458 \\
-.867 \\
.476 \\
-.297 \\
.522 \\
-.251 \\
.971 \\
-1.715 \\
-.203 \\
-1.033 \\
2.310 \\
.561 \\
1.026 \\
.898 \\
-.054 \\
-.011 \\
1.575 \\
.795 \\
-.006 \\
-.375 \\
-.221 \\
.350 \\
-.005 \\
-.380\end{array}$ & $\begin{array}{l}.845 \\
.845 \\
.845 \\
.845 \\
.845 \\
.845 \\
.845 \\
.845 \\
.845 \\
.845 \\
.845 \\
.845 \\
.845 \\
.845 \\
.845 \\
.845 \\
.845 \\
.845 \\
.845 \\
.845 \\
.845 \\
.845 \\
.845 \\
.845 \\
.845\end{array}$ & $\begin{array}{l}-.720 \\
-2.117 \\
.069 \\
-.504 \\
-.755 \\
-.016 \\
-.256 \\
-1.147 \\
2.990 \\
-.521 \\
1.465 \\
5.437 \\
-1.744 \\
-.257 \\
1.299 \\
-3.194 \\
-3.275 \\
2.191 \\
-.041 \\
-3.281 \\
-2.066 \\
-1.394 \\
-.133 \\
-3.281 \\
-2.069\end{array}$ & $\begin{array}{l}1.741 \\
1.741 \\
1.741 \\
1.741 \\
1.741 \\
1.741 \\
1.741 \\
1.741 \\
1.741 \\
1.741 \\
1.741 \\
1.741 \\
1.741 \\
1.741 \\
1.741 \\
1.741 \\
1.741 \\
1.741 \\
1.741 \\
1.741 \\
1.741 \\
1.741 \\
1.741 \\
1.741 \\
1.741\end{array}$ \\
\hline
\end{tabular}

Table 1: Statistical evaluation for different Parameters in the Sagar Lake's water Samples in Sagar City

Dependent variable is $\mathrm{DO}$,

\begin{tabular}{|l|l|l|l|}
\hline Variable & Coefficient & Variable & Coefficient \\
\hline Intercept & 9.6259766 & RESI.CHLORINE & 16.820313 \\
TEMPERATURE & .4935913 & PHOSPHATE & -1.711731 \\
COLOUR & -.2397308 & NITRATE & .4920654 \\
pH & .5554199 & AMMONIA & -14.97168 \\
TRRBIDITY & -.2132874 & TH & -.008172 \\
BOD & .1563416 & TEMP. HARD & -.0277519 \\
COD & 02528019 & PERM. HARD & .0210648 \\
CONDUCTIVITY & -15.96021 & Ca HARDNESS & .0290823 \\
ALKALINITY & .104413 & Mg HARDNESS & .0430527 \\
TS & .0294876 & FLUORIDE & -3.734375 \\
TSS & .4076538 & IRON & -1.878845 \\
TDS & -.0119228 & Ca CONTENT & -.0204894 \\
CHLORIDE & .0416107 & Mg CONTENT & .6856232 \\
\hline
\end{tabular}

R-Square $=0.0$

Adjusted R-Squre $=1.25$

Cohen's f-square $=0.0$, a small effect size
25 independent variables, 6 Cases.

\begin{tabular}{|l|l|l|l|l|l|}
\multicolumn{9}{c|}{ Analysis of variance to Test Regression Relation } \\
\hline Source & Sum of Sqa & df & Mean Sq & p-value \\
\hline Regression & 2547.0231 & 25 & 101.88092 &. \\
\hline Error & -2546.369 & -20 &. & N.A. \\
\hline Total & .65415 & 5 & & \\
\hline
\end{tabular}

Note: - A low p-value suggests that the dependent variable DO may be linearly related to independent variable (s)

Table 4: Multiple Regression Analysis for different Parameters in the Lake water Samples of Sagar city.

by micro-organisms and from gas exchange with the atmosphere. It is also discharged into water bodies by municipal or community waste. As a result, creatures such as fish, shrimp, and especially immobile bottom dwellers die off. Clothes washing at Dhobi/Chakra Ghat should be strictly banned because it not only causes organic, inorganic and biological contamination but also increase the detergents content. It hampers oxygen diffusion rate in the Lake water affecting the self purification capacity as well as other biological activities.

\section{Conclusion}

All the water quality parameters of lake out of the maximum permissible limit set by WHO. Eutrophication promotes excessive plant growth and decay, favors certain weedy species over others, and is likely to cause severe reductions in water quality. DO levels decline to hypoxic levels, fish and other marine animals suffocate. Finally this ecosystem experiences an increase in nutrients, species such as algae experience a population increase (algal bloom). Hence lake water cannot be much fit for drinking, irrigation and domestic used. The average of alkalinity has exceeded due to improper drainage system. It is recommended that lakes water analysis should be carried out from time to time to monitor the rate and kind of contamination. A regular environmental monitoring programme must be conducted in 
Citation: Pathak H, Pathak D (2012) Eutrophication: Impact of Excess Nutrient Status in Lake Water Ecosystem. J Environ Anal Toxicol 2:148. doi:10.4172/2161-0525.1000148

Page 4 of 5

\begin{tabular}{|c|c|c|c|c|}
\hline $\begin{array}{l}\text { Dependent } \\
\text { Variable }\end{array}$ & $\begin{array}{l}\text { Independent } \\
\text { Variable }\end{array}$ & Regression equation & Slope & $\mathbf{R}^{2}$ \\
\hline $\mathrm{DO}_{\text {mean }}$ & $\mathrm{BOD}_{\text {mean }}$ & $\mathrm{DO}=31.93+1.551{ }^{*} \mathrm{BOD}$ & 1.551 & 0.007 \\
\hline $\mathrm{DO}_{\text {mean }}$ & $\mathrm{COD}_{\text {mean }}$ & $\mathrm{DO}=303.1-66.81 * \mathrm{COD}$ & -66.81 & 0.834 \\
\hline $\mathrm{DO}_{\text {mean }}$ & $\begin{array}{l}\mathrm{BOD}_{\text {mean }} \\
\mathrm{COD} \text { mean }\end{array}$ & $\mathrm{DO}=2.6645816+.0081708 * \mathrm{BOD}+.0021325 * \mathrm{COD}$ & & .0323 \\
\hline $\mathrm{DO}_{\text {mean }}$ & Alkalinity $_{\text {mean }}$ & $\mathrm{DO}=493-33.58{ }^{*}$ alkalinity & -33.58 & .228 \\
\hline $\mathrm{DO}_{\text {mean }}$ & TDS $_{\text {mean }}$ & $\mathrm{DO}=250.7+184.5 * \mathrm{TDS}$ & 184.5 & .113 \\
\hline $\mathrm{DO}_{\text {mean }}$ & $\mathrm{pH}_{\text {mean }}$ & $\mathrm{DO}=3.757+1.718^{*} \mathrm{pH}$ & 1.718 & .665 \\
\hline $\mathrm{DO}_{\text {mean }}$ & Chloride $_{\text {mean }}$ & $\mathrm{DO}=-112.1+74.33 *$ Chloride & 74.33 & 0.579 \\
\hline $\mathrm{DO}_{\text {mean }}$ & Residual Chlorine $_{\text {mean }}$ & $\mathrm{DO}=0.092+0.039 *$ Residual Chlorine & 0.039 & 0.016 \\
\hline $\mathrm{DO}_{\text {mean }}$ & o-Phosphate $_{\text {mean }}$ & $\mathrm{DO}=9.664-1.510$ * o- Phosphate & -1.510 & 0.465 \\
\hline $\mathrm{DO}_{\text {mean }}$ & Nitrate $_{\text {mean }}$ & $\mathrm{DO}=13.60-1.171 *$ Nitrate & -1.17 & .191 \\
\hline $\mathrm{DO}_{\text {mean }}$ & Ammonia $_{\text {mean }}$ & $\mathrm{DO}=0.442+0.002 *$ Ammonia & 0.002 & .001 \\
\hline $\mathrm{DO}_{\text {mean }}$ & $\begin{array}{l}\text { TDS }_{\text {mean }} \\
\text { Chloride }_{\text {mean }}\end{array}$ & $\mathrm{DO}=2.8947197+.0006395 *$ TDS $-.0021692{ }^{*}$ Chloride & & 0.151 \\
\hline $\mathrm{DO}_{\text {mean }}$ & $\begin{array}{l}\text { TDS mean Chloride mean, } \\
\text { Residual Chlorine }_{\text {mean }}\end{array}$ & $\begin{array}{l}\text { DO }=3.2000125+.0003551 * \text { TDS }-.0007378 * \text { Chloride }-1.125849 * \text { Residual } \\
\text { Chlorine }\end{array}$ & & 0.2344 \\
\hline $\mathrm{DO}_{\text {mean }}$ & $\begin{array}{l}\text { TDS mean Chloride mean, } \\
\text { Residual Chlorine }_{\text {mean }} \\
\text { o-Phosphate }_{\text {mean }}\end{array}$ & $\begin{array}{l}\mathrm{DO}=1.8955758+.000345 * \text { TDS }-.0013377 * \text { Chloride }-2.049152 * \text { Residual } \\
\text { Chlorine }+.2572442 * \text { o-Phosphate }\end{array}$ & & 0.4843 \\
\hline $\mathrm{DO}_{\text {mean }}$ & $\begin{array}{l}\text { TDS mean Chloride mean, } \\
\text { Residual Chlorine }_{\text {mean }} \\
\text { o-Phosphate }_{\text {mean }} \\
\text { Nitrate }_{\text {mean }}\end{array}$ & $\begin{array}{l}\mathrm{DO}=56.332194+.0217746 * \text { TDS }-.1663759 * \text { Chloride+ } 51.923978 \\
{ }^{*} \text { Residual Chlorine+ } .1293998 \text { * o-Phosphate }-6.342301 \text { * Nitrate }\end{array}$ & & 0.0 \\
\hline $\mathrm{DO}_{\text {mean }}$ & $\begin{array}{l}\text { TDS Chloride mean, } \\
\text { Residual Chlorine }_{\text {mean }} \\
\text { o-Phosphate }_{\text {mean }} \\
\text { Nitrate }_{\text {mean }} \\
\text { Ammonia }_{\text {mean }}\end{array}$ & $\begin{array}{l}\mathrm{DO}=8.2230225-.0023214 * \text { TDS }+.0472021 * \text { Chloride }-25.00903{ }^{*} \text { Residual } \\
\text { Chlorine }+.2979269{ }^{*} \text { o-Phosphate }+1.4023132{ }^{*} \text { Nitrate }-44.00537{ }^{*} \text { Ammonia }\end{array}$ & & 0.0 \\
\hline $\mathrm{DO}_{\text {mean }}$ & $\begin{array}{l}\text { Total } \\
\text { hardness }_{\text {mean }}\end{array}$ & $\mathrm{DO}=1128-190.9 *$ Total hardness & -191 & 0.572 \\
\hline $\mathrm{DO}_{\text {mean }}$ & Temporary hardness $_{\text {mean }}$ & $\mathrm{DO}=1.6116+.0036 *$ Temporary hardness & & .338 \\
\hline $\mathrm{DO}_{\text {mean }}$ & Permanent hardness $_{\text {mean }}$ & $\mathrm{DO}=3.2268-.0007{ }^{*}$ Permanent hardness & & .016 \\
\hline $\mathrm{DO}_{\text {mean }}$ & Calcium hardness $_{\text {mean }}$ & $\mathrm{DO}=672.9-78.98 *$ Calcium hardness & -78.98 & 0.353 \\
\hline $\mathrm{DO}_{\text {mean }}$ & Magnesium hardness $_{\text {mean }}$ & $\mathrm{DO}=455.6-111.9 *$ Magnesium hardness & -111.9 & .554 \\
\hline $\mathrm{DO}_{\text {mean }}$ & $\begin{array}{l}\text { Temporary hardness } \\
\text { Pean } \\
\text { Permanent hardness }_{\text {mean }}\end{array}$ & $\begin{array}{l}\mathrm{DO}=1.6642151-.0034803 * \text { Temporary hardness }-.0002226 \text { * Permanent } \\
\text { hardness }\end{array}$ & & 0.338 \\
\hline $\mathrm{DO}_{\text {mean }}$ & $\begin{array}{l}\text { Calcium hardness } \\
\text { Magnean } \\
\text { Magium hardness }_{\text {mean }}\end{array}$ & $\begin{array}{l}\mathrm{DO}=.2102607+.0078471 * \text { Calcium hardness }-.0036364 * \text { Magnesium } \\
\text { hardness }\end{array}$ & & .7292 \\
\hline $\mathrm{DO}_{\text {mean }}$ & Fluoride $_{\text {mean }}$ & $\mathrm{DO}=-0.046+0.422 *$ Fluoride & 0.422 & 0.357 \\
\hline $\mathrm{DO}_{\text {mean }}$ & Iron $_{\text {mean }}$ & $\mathrm{DO}=1.778+.416 *$ Iron & .416 & .009 \\
\hline $\mathrm{DO}_{\text {mean }}$ & Fluoride $_{\text {mean }}$ Iron $_{\text {mean }}$ & $\mathrm{DO}=4.5251761-1.030661$ * Fluoride -.0115327 * Iron & & 0.478 \\
\hline
\end{tabular}

Table 5: Regression Analysis of chemical Parameters with DO in Lake's water Samples of Sagar city (Monsoon 2007 to Pre Monsoon 2011 )

Sagar Lake for pollution abatement needs to be initiated as per WHO guidelines, it would be useful for pollution abatement program to be implemented for an effective result. The consumption of unsafe water has been implicated as one of the major causes of this disease. As one of the famous Lake, as well as tourist point of view Sagar Lake water should be preserved for the protection of natural environment.

\section{References}

1. Pathak H (2011) Doctoral thesis (submitted), Dr. H. S. Gour Central University, Sagar, Madhya Pradesh, India.

2. Pathak H, Limaye SN (2011) Study of Seasonal Variation in Groundwater Quality of Sagar City (India) by Principal Component Analysis. J Chem 8: 20002009.

3. Pathak H, Limaye SN (2011) Interdependencey between physicochemica water pollution indicators: a case study of river Babus, Sagar, M.P., India. Analele UniversităNiii din Oradea - Seria Geografie 1: 23-29.

4. Pathak H, Limaye SN (2011) A mathematical modeling with respect to DO for environmentally contaminated drinking water sources of Sagar city (M.P.), India: A case study. Ovidius University Annals of Chemistry 22: 87-93.
5. Pathak H, Limaye SN (2011) Seasonal study with interpretation of the chemical characteristics of water Lake in reference to quality assessment: A case study, Analele UniversităNiii din Oradea - Seria Geografie 2: 233-238.

6. Pathak H, Limaye SN (2012) Assessment of Physico-Chemical Quality of Groundwater in rural area nearby Sagar city, MP, India, Advances in Applied Science Research (Pelagia Research Library) 3: 555-562.

7. Pathak H, Pathak D, Limaye SN (2012) Studies on the physico-chemical status of two water bodies at Sagar city under anthropogenic Influences. Advances in Applied Science Research (Pelagia Research Library) 3: 31-44.

8. Pathak H, Limaye SN (2012) Multivariate evaluation of fluoride contamination in ground water samples of Sagar city, M.P., India: A case study, accepted by Instasci. J Chem 2: 1.

9. Pathak H, Limaye SN, Ground and Tap water Quality assessment of Saga city especially in terms of saturation index, accepted by BULLETIN OF THE POLYTECHNIC INSTITUTE OF IAŞI.

10. Pathak H, Limaye SN (2012) A water quality index mathematical modeling of water samples of Rajghat, water supply reservoir Sagar (MP) with respect to total dissolved solids: A regression analysis, BULLETIN OF THE POLYTECHNIC INSTITUTE OF IAŞI 1: 85-104.

11. Pathak H, Limaye SNP (2011) Pollumeter: a Water Quality Index Model for the Assessment of Water Quality. The Green Pages. 
Citation: Pathak H, Pathak D (2012) Eutrophication: Impact of Excess Nutrient Status in Lake Water Ecosystem. J Environ Anal Toxicol 2:148. doi:10.4172/2161-0525.1000148

Page 5 of 5

12. Wu FF, Wang X (2012) Eutrophication Evaluation Based on Set Pair Analysis of Baiyangdian Lake, North China. Procedia Environmental Sciences 13: 10301036.

13. Florian T, Nicole R, Cinzia B, Mauro T, Thierry A, et al. (2012) Characterization of fecal indicator bacteria in sediments cores from the largest freshwater lake of Western Europe (Lake Geneva, Switzerland). Ecotoxicol Environ Saf 78: $50-56$
14. APHA (2005) Standard methods for the examination of water and waste water (21stedition). American Public Health Association, Washington, DC, USA.

15. WHO (1984) Guidelines for drinking water quality, Recommendations WHO Geneva 